\title{
Teaching ethics through court judgments in Finance, Accounting, Economics and Business
}

\section{Rafael Robina Ramirez}

Business and Sociology Department, University of Extremadura, Spain, rrobina@unex.es

DOI: http://dx.doi.org/10.5324/eip.v11i1.1938

This is an open access article distributed under the terms of the Creative Commons
Attribution 4.0 International License, which permits unrestricted use, distribution, and
reproduction in any medium, provided the original author and source are credited.

The current environment of business and financial corruption in Spain has increased in recent years. In order to reduce the scope of this problem, the Spanish Criminal Code (L.O. 1/2015) has introduced codes of conduct and ethics to encourage a new culture of respecting laws for companies and employees. An Educational Innovation Group at the University of Extremadura has proposed a cross-sectional model to study ethics, in an effort to address concerns about the consequences of illegal acts in society and companies. Students in Business, Finance and Accounting are required to practice ethical decision-making through court judgments in order to develop "ethical competences". These competences are included in the European Higher Education Area and the Official University Education in Spain, specifically in the Royal Decree 1393/2007, of 29 October through cross-sectional competences within the academic programmes. The results of the study show that a high percentage of students validate this methodology as a way of improving ethical decision-making skills at University that will be applied to future business practices.

Keywords: Ethics, court judgments, finance and accounting, companies, compliance, teaching

\section{Introduction}

Due to recent Spanish business scandals between 2014 and 2015, the General Council of the Judiciary passed more than 4000 judgments related to business matters. These judgments have been published in a database held by the General Council of the Judiciary in Spain. They are organised into different sections, namely: unfair competition (1006), labour exploitation (1439), the use of public information for private purposes (356), tax falsehoods and inaccurate documentation (943), strategies for tax evasion (271), flight of capital (292) and biased economic information (94). This study highlights some examples of illegal acts from Spanish Criminal Law: a) Judgment 10/2015 of the Provincial Court of Pontevedra, in which a company is assessed for tax evasion (art. 305); b) Judgment 
161/2015 of the Provincial Court of Baleares, in which an employer is condemned for illegal acts related to flight of capital (art. 301. 1st, 2nd and 3rd); c) Judgment 1/2014 of the Provincial Court of Guadalajara, based on labour exploitation (art. 318 bis 1 st and $3 \mathrm{rd}$ ) and crimes against foreign employees (art. 318 bis 1st); and d) Judgment 351/2015 of the Provincial Court of Alicante that mentions unfair competition by disclosing a company's private secrets (art. 197. 3rd and 198 ${ }^{\circ}$ ). This type of illegal behaviour in Spanish companies has increased in recent years mainly due to the pressure they are subject to in order to reach their initially envisaged goals - regardless of whether or not this is achieved legally. As a consequence, the Spanish Criminal Code (L.O. 5/2010, of 23 June, the amended L.O. 1/2015, of 1 July) introduced a new article, namely Article $31.5^{\text {a }}$, to regulate these matters. Its main purpose is to prevent illegal behaviour from happening in companies by implementing "special control and surveillance measures" and to ensure "compliance with the law". Moreover, recent judgments passed by the Spanish Supreme Court (154/2016, of 29.02.2016 and 221/2016, of 16.03.2016) condemn several companies for illegal business and financial acts, and for not having implemented such special surveillance measures. Ever since the "corporate compliance" process was introduced, the results of these judgments have primarily been: economic penalties, claims for damages, loss of reputation and loss of competitiveness. Sometimes the judgments even have devastating results that must be resolved (Rotsch, 2012, Kuhlen, 2013, Bock, 2013).

Under current Spanish Criminal Law, one must establish whether "the financial or business crime committed by the employee was made possible or enabled by the company due to the absence of a culture of respect towards the law, as a source of inspiration for the performance of its organisational structure" (Supreme Court, 29/02/2016). So, the need "to promote a culture of respect towards the law" awakens the interest of employers to analyse the ethical implications involved in doing business.

There are three reasons for taking the new perspective of Spanish Criminal Law into account when analysing ethical implications through judgments with students: 1) The recently-amended L.O. 1/2015, of 1 July, compels all companies to implement "special control and surveillance measures" based on ethical codes; 2) In order to build a culture of respect towards the law, it is absolutely necessary to create and sustain a culture of ethics among employees and employers to successfully fulfil such mandatory measures; and 3) This culture of ethics must begin and be learnt at university.

An Educational Innovation Group, formed by 15 teachers in the Financial, Accounting and Business areas, proposed a cross-sectional model study of ethics in the framework of the recently amended L.O. 1/2015, with 467 participating students. Through the use of judgments, students reflected on the illegal acts and unethical behaviour committed by a sentenced employee, making ethical decisions toward improving the ethics at university and in future employment scenarios within a company (as employers or employees). This methodology aligns with "ethical competences", which are explicitly included in the academic programmes provided by the Royal Decree 1393/2007, of 29 October on Official University Education in Spain.

This regulation defines "competences" (cross-sectional) as the abilities "acquired by students" to make moral judgments as a part of moral reasoning and to develop 
the ability to reason correctly about what 'ought' to be done in a specific situation. Moreover, students are also required to develop their "moral imagination" through using judgments to increase their ability to see situations through the eyes of others and to solve a problem as if they were the person in charge of the company (Biss, 2014). Hence, it is proposed that students, even without prior knowledge of ethical theorising, could deal with comparable ethical situations (Maclagan, 2015) based on "illegal acts and unethical behaviour" in real companies. Ethical thinking can also help develop a moral sense (Sia, 2010) among people at university, as well as in their future jobs, whether they are employers or employees.

In order to study the theoretical aspects, the second part of this paper reviews and analyses the literature to accurately describe the ethical content based on: 1) Teaching ethics at the university through cross-sectional subjects, 2) Teaching through the use of court judgments based on "legal/illegal acts and ethical/unethical behaviour", 3) Ethics in future employment within a company, under the framework of the recently amended L.O. 1/2015, of 1 July which introduces a culture of respect towards the law linked to a successful blending of compliance with ethics, and 4) Consequences for individuals, employees, businesses and society.

\section{Literature Review Teaching ethics at the university through cross-sectional subjects}

The recent business scandals - mainly in Spain, but also worldwide - that are reflected in a high number of criminal sentences, justify why teaching ethics to students in the areas of Finance and Accounting, and Business and Economy has gained so much interest (Buchan 2005, Johl et al., 2012, Marques \& Azevedo Pereira 2009, Svanberg 2011, Bampton \& Cowton 2013). Most of the sentenced illegal acts are well supported by the literature, such as: unfair competition receiving unjustified business favours (Gili Pascual, 2007), labour exploitation (MorenoJiménez; Rodríguez Muñoz, 2006), the use of public information for private purposes (Bajo Fernández, 1998), tax falsehoods and inaccurate documentation (Bacigalupo, 2007), strategies for tax evasion (Camargo Hernández, 2005), flight of capital (Alvarez Pastor; Eguidazu Palacios 2006), among others.

Ordinarily, business scandals prioritise self-interest over compliance with the law. Unfortunately, such corrupt actions are barely mentioned in business and financial courses at the university.

In addition to positive examples of ethics education at the University of Extremadura (Dellaportas et al. 2006; Welton et al. 1994; Gardner 2007), utilitarian, pragmatic and superficial perspectives are still commonly taught in Finance and Business coursework (Gray et al, 1994). That is why universities are sometimes accused of emphasising business optimisation, efficiency and effectiveness by promoting the maximization of monetary benefits to the detriment of other values (Currie et al., 2010; Starkey \& Tempest, 2009).

Furthermore, it is important to consider values such as honesty, loyalty, fairness, incorruptibitily, and integrity, especially when $95 \%$ of a large group of business students have been shown to have cheated during high school or college (Brenton, 1995). More attention should be paid not only to academic excellence, dialogic pedagogy and the social significance of teaching materials (Zhonghai 2012) but also to ethical reasoning in order to link business and society (Carroll \& Buchholtz, 
2008). Consequently, teaching is not only a technical endeavour, but also an ethical and moral one (Campbell 2003, Shapira-Lishchinsky 2011, 648, Sanger \& Osguthorpe 2005, 2013, Mahony, 2009, Willemse, et al., 2005, 2008). This by no implies a rigid set of rules. Rather, it provides a framework by which individuals and organisations can determine and evaluate their actions from the perspective of essential moral principles and values (Epstein 1989).

Unfortunately, these moral principles and values are not clearly reflected in education programmes as yet (Sanger \& Osguthorpe 2013: 176), which makes the specific challenge of teaching ethics even more important. Also, in the fields of Accounting and Finance, ethics instruction is undoubtedly the hardest part of teaching (Argandoña 1999), primarily because teachers are not specialists in these areas of knowledge (Oddo 1997). The teachers themselves suffer from a lack of professional knowledge of ethics (Colnerud, Granström 2002).

Should one teach ethics as a single subject or make scattered references to ethics in all subjects? The literature supports different perspectives in this respect. Some authors propose a "vertical approach" to ethics, such as: studying philosophical principles in class to strengthen the ethical decisions to be taken by students (Felton \& Sims 2005; McDonald 2004); attending independent seminars on ethics (Oddo 1997, 293); or including courses on ethics in academic curricula as an additional subject (Moore 2004, Ritter 2006, Thornberg 2008). Others stress that students need realistic business problems to deal with ethical dilemmas from a cross-sectional perspective (Zych, 1999) or management lessons through movies with corporate, entrepreneurial and ethics views (Higgins \& Striegel's 1999, 2003).

Since the Bolonia Declaration, in 1999, the European Higher Education Area has emphasised academic "competences". DESECO-OCDE, (2002: 4) goes beyond academic knowledge in order to develop competences through the curricula that allow students to strengthen their attitudes and psychological ability to face social and economic problems. Also, thanks to the ethic of the Tuning Educational Structures in Europa Project (2002: 21), each academic programme's coursework must include a personal cross-sectional competence framework of behaviour (Bolivar, 2005). This perspective moves away from a vertical approach (McDonald \& Donleavy 1995) to a cross-sectional one (Hernández et al., 2007).

Two reasons support this approach:

1) In order to link action-based pragmatic teaching with ethical meaning and reflection (Schön 1992: 9), the Spanish Royal Decree 55/2005, 21 of January pointed out the need to "promote the achievement by students of a university education that combines basic general knowledge and general competences related to their comprehensive training in each subject". In other words, competences must be at the heart of the curricula's aim (Royal Decree 1393/2007, of 29 October). So, although it is possible to teach ethics through a vertical approach, the European Higher Education Area and Official University Education in Spain recommend teaching ethics through "ethical competences";

2) In our working proposal, based on learning ethics through court judgments, students have to make ethical decisions in order to correctly implement the "surveillance measures" in the framework of the recently amended L.O. 1/2015. Using this methodology, students are able to link illegal acts with ethical decisions. To properly understand this methodology, it is necessary to understand the 
relationship between legal/illegal acts and ethical/unethical behaviour as conveyed in the next paragraph.

\section{Teaching through court judgments based on "legal/illegal acts and ethical/unethical behaviour"}

In order to outline cross-sectional cases based on court judgments, we must first explain the relationship between "ethics" and "rights", since this is the central aspect of the methodology.

Although the basic content (human actions) remains unchanged between the two concepts on the basis of the moral unity of people, they differ in the "formal aspect" or the perspective from which their knowledge is addressed. On the one hand, the ethical perspective refers to the intrinsic goodness or badness of human action according to our behaviour. On the other hand, the perspective of a right recognised by law looks at behaviour from a relational and social approach, i.e. in relation to other actions. This perspective is aimed at respecting those rights recognised by law and the rights of others. Thus, the objective of a "right" does not consist in a person fulfilling himself or herself while being fair at the same time, but in every man's right being respected (Hervada 1992). Therefore, the science of law is not part of morality and consequently, a lawyer is not a moralist.

"Ethics", for example, ensures that the loans granted by financial institutions are not abusive, whereas "lawyers care about the same thing, but for other reasons: to ensure that everyone's rights are respected, so that everyone receives what they are entitled to and that there is a just social order" (Hervada 1992: 416). However, to reach this social, distributive and participatory justice, it becomes necessary to care for the ethical dimensions of human action (Boylan \& Woolsey 2015: 62) coinciding with the core content of the object studied.

Thus, while "illegal business practices" are those that violate existing laws, "unethical practices" may or may not violate any laws, but are practices that society deems less than acceptable (Duizend \& McCann 1998). To prevent the first, i.e. illegal business practices, the legislator has to establish legal barriers (Wines 2008: 483), and to prevent unethical practices, ethical decisions should be taken, not only to avoid damaging sanctions, but also to behave correctly and in a socially acceptable manner.

Our field of study is not so much about analysis of the breach of a norm, but rather about the unethical behaviours such violations entail and the ethics that could have prevented them. However, in the real world, employees and entrepreneurs do not usually differentiate between illegal and unethical acts (Duizend \& McCann 1998).

For this paper, we extracted both acts that are accepted by the legal rules and ones that are not, as well as their ethical consequences from the 25 court judgments analysed in this study. Then, we classified these acts and their unethical consequences to get a better idea of the relationship between the norms and their ethical/unethical consequences in companies. The results of this classification can be seen in Figure 1 below. 
Figure 1: Comparison between acts accepted or prohibited by the law and their ethical or unethical consequences

\begin{tabular}{|l|l|l|}
\hline Behaviour & Ethical consequences & Unethical consequences \\
\hline Acts accepted by the law & $\begin{array}{l}\text { High percentage } \\
1^{\text {st }} \text { case }\end{array}$ & $\begin{array}{l}\text { Low percentage } \\
2^{\text {nd }} \text { case }\end{array}$ \\
\hline $\begin{array}{l}\text { Acts prohibited by the } \\
\text { law }\end{array}$ & $\begin{array}{l}\text { Very low percentage } \\
3^{\text {rd }} \text { case }\end{array}$ & $\begin{array}{l}\text { High percentage } \\
4^{\text {th }} \text { case }\end{array}$ \\
\hline
\end{tabular}

Usually, behaviours accepted by law produce a high percentage of ethical consequences for society, businesses and employees ( $1^{\text {st }}$ case). Similarly, acts prohibited by law are most likely to create unethical consequences ( $4^{\text {th }}$ case), like crimes or misdemeanours in the fields of the Spanish Criminal Code (theft, murder, assault, rape, bribery, etc.) or administrative offences (lack of required licences or permits to build or open a business, failure to observe safety standards, etc.).

In the $2^{\text {nd }}$ case, there are two options: 1 ) the law is clearly unjust towards people's dignity, the safety of a territory or its people, putting them in a risky situation. In this case, the consequences would always be unethical but not illegal, because the behaviour or act has been officially accepted by law; 2) if the law is just and the acts are accepted by the law, there may be no ethical consequences. In this case, it was noted that many completely legal actions are not always entirely ethical. Different examples reflect this, such as: "setting wages lower than worker productivity", "using public information for private purposes without compromising the performance and efficiency of the company", "influencing the recruitment process according to personal affinities", etc.

As regards the $3^{\text {rd }}$ case, acts prohibited by law are not always synonymous with unethical consequences. This means that some behaviours that are not accepted by the law may produce ethical consequences, although at a very low percentage. According to the court judgments analysed herein, this would only represent $2 \%$ of the cases. For example, certain humanitarian circumstances are likely to have different legal consequences, creating a distance between ethical and legal perspectives. This is because "morality" and "legality" do not coincide in what concerns their formal approach, as mentioned above.

Any of the four cases described above may arise in any company. In fact, morality and legality are connected in the Spanish Criminal Code through the culture of respect towards the law to ensure compliance with the law, as mentioned in the introduction. Students will be able to see how companies' ethical culture increases in the Spanish labour market when based on mandatory surveillance measures according to the above-mentioned law.

All these processes must be taught during university education to help students understand and support this compliance with the law through ethical behaviour, giving them the necessary tools to solve future ethical problems through crosssectional ethical cases.

\section{Ethics in future employment within a company: "Compliance"}

The term "compliance" means knowing and following all relevant laws, rules, policies, regulations and standards, and ensuring that organisations adhere to all applicable legal requirements (Wulf 2012). Being compliant not only requires the implementation of an effective internal control system (Namiri \& Stojanovic 2007), 
but also having a set of codes of conduct. This requires implementing an ethics and compliance programme before establishing legal standards (Wulf 2012).

Whether establishing ethical principles or codes of conduct, companies need to build confidence between the employer or boss and the employees in order "to promote a culture of respect towards the law" (Supreme Court, 20/02/2016). Although these codes are not yet practiced routinely in companies (Pater Van Gils 2003), they are indeed models for cooperation between the operational processes of the organisation and its management (Wieland 2015). They are also a point of orientation for professional action and legal evaluation (Hubig 2001). These principles or codes can be used as a basis for operational requirements, as well as operational prohibitions. Moreover, they provide methods for getting help or advice, and procedures employees can follow in the event of having to report a violation. Employees should be guided towards the right ethical behaviour in such a way that they know how to behave in ambiguous situations. Some organisations tend to use their codes of conduct to cope with differences in ethical values between different cultures and to serve as a tool for decision-making processes (Adam \& Fachman-Moore 2004).

For instance, the OECD elaborates its own set of guidelines related to business ethics for multinational companies. Their recommendations highlight aspects such as business ethics, human rights, environment, fraud, competition or bribery (OECD 2009). Such guidelines also provide voluntary standards for companies to take into account along with the relevant laws. The idea is to ensure that operations do indeed comply with the legal regulations and government policies in all countries involved (OECD 2008).

The aim of these procedures is to minimise any negative consequences, not only for employees but also for companies and society in general.

\section{Consequences for individuals, employees, company and society}

To raise students' awareness of how to avoid illegal conduct or crimes and their consequences in their future jobs, they need to be aware of the negative effects crimes have on individuals, companies and society (Godson \& Kenney 2000). These negative effects have specific consequences for individuals, employees and companies if they go beyond the legal limit.

In order to catalogue the consequences of ethical behaviour of individuals, employees, companies and society, we must contextualise the meaning of these consequences:

1. Individuals: especially among university students, those who commit an illegal act will receive an undesirable mark, not only as regards their reputation but also as part of their academic file.

2. Employees: those consequences referring directly or indirectly to employees' rights.

3. Companies: damages caused to productivity, profits, image, trade and other negative consequences.

4. Society: if the impact of the illegal act extends beyond the boundaries of a company and affects national interests and financial markets as a whole, the consequences, as understood by Marinucci Dolcini (2002) could be: flight of capital, falling stock prices, the ruin of small savers, the involvement of the banking system or a collective dismissal of employees. 
In Figure 2, we move from the general consequences of "prohibited and accepted acts" and "ethical decisions" in Figure 1, to "ethical consequences for employees, companies and society".

We also include "omissions" with performing actions and also "ethical decisions". Whereas "omissions" are formally included within the scope of legal regulations, "ethical decisions" are omitted. Hence, our work focuses on filling these gaps and providing solutions that legal regulations cannot. For example, in omissions, we can outline a few examples, such as "insensitivity to the demands and concerns of employees", "disregard for the negative consequences of the company's activity with regards to the environment", or "exception for discharges of illegal chemicals". Along with the stated omissions, there is a broad range of "ethical decision" options for each topic.

Figure 2: Consequences of the acts, omissions and ethical decisions outlined in court sentences

\begin{tabular}{|l|l|l|l|l|}
\hline $\begin{array}{l}\text { Ethical } \\
\text { consequences }\end{array}$ & $\begin{array}{l}\text { Prohibited } \\
\text { acts, } \\
\mathbf{1}^{\text {st }} \text { case }\end{array}$ & $\begin{array}{l}\text { Accepted acts } \\
\text { or omissions, } \\
\mathbf{2}^{\text {nd }} \text { case }\end{array}$ & $\begin{array}{l}\text { Accepted acts } \\
\text { or omissions, } \\
\mathbf{3}^{\text {rd }} \text { case }\end{array}$ & $\begin{array}{l}\text { Ethical } \\
\text { decisions } \\
\mathbf{4}^{\text {th }} \text { case }\end{array}$ \\
\hline $\begin{array}{l}\text { For } \\
\text { individuals } \\
\text { and } \\
\text { employees }\end{array}$ & $\begin{array}{l}\text { Very } \\
\text { negative }\end{array}$ & $\begin{array}{l}\text { Indifferent or } \\
\text { negative }\end{array}$ & Positive & Very positive \\
\hline $\begin{array}{l}\text { For } \\
\text { companies }\end{array}$ & $\begin{array}{l}\text { Very } \\
\text { negative }\end{array}$ & $\begin{array}{l}\text { Indifferent or } \\
\text { negative }\end{array}$ & Positive & Very positive \\
\hline For Society & $\begin{array}{l}\text { Social } \\
\text { disapproval }\end{array}$ & $\begin{array}{l}\text { Social } \\
\text { disapproval }\end{array}$ & Social approval & Social approval \\
\hline
\end{tabular}

The consequences of "prohibited acts", "accepted acts or omissions" and "ethical decisions" for individuals, employees, the company and society from a social standpoint can be divided into four cases, from lowest to highest in ethical terms.

In the $1^{\text {st }}$ case, all prohibited acts, as mentioned above, generate unethical behaviour, which is very negative for employees and company alike, generating social disapproval if discovered.

In the $2^{\text {nd }}$ case, we note to a lesser extent that acts accepted by the law and certain omissions can cause unethical consequences with an indifferent" or negative effect both to the employees and the company. This generally produces social disapproval when known.

From another perspective, although the $3^{\text {rd }}$ case refers to the same casuistry as the previous case, a large majority of actions accepted by the legal system yield a positive effect on employees and the company, both of which are accompanied by social and personal approval.

The $4^{\text {th }}$ case addresses ethical decisions, found mainly in the codes of practice fostered by corporate compliance in companies. Undoubtedly, at this stage, we are seeing behavioural excellence with positive implications for both the employees and the company, and with high personal and social connotations of approval.

In the last case, ethical decisions will depend not only on the employees' values but also on their operating principles. Decision-making that focuses on being more compliant with companies' organisational rules must be learned at university. 
The next section addresses methodology based on the description of acts, omissions and ethical decisions outlined above. We classify not only implicit illegal acts and omissions found in the judgment, but also the ethical choices made by students in order to avoid unlawful behaviour at the university and companies.

\section{Methodology and Methods}

After the Innovation Project of the University of Extremadura was given the green light in 2014, fifteen teachers from the Business Management and Sociology, Finance and Accounting, and Economy departments formed a working group. The group called itself the Educational Innovation Group. Their aim was twofold: on the one hand, they intended to articulate the literature review process, to define and test several hypotheses and to determine the phases of the project; and on the other hand, to organise the teachers who would be conducting the study in their classrooms.

Based on the literature review, the group proposed several hypotheses related to: 1) Methodology of studying ethics through cross-sectional competences at university; 2) Ethical content based on the differences between "illegal acts" and "unethical behaviour" and their consequences for students, employees, companies and society; and 3) Ethical approaches to students' future employment within a company.

1. $\mathrm{H}_{1}$ - Students highly value the study of ethics through court judgments based on legal/illegal acts and ethical/unethical behaviour.

2. $\mathrm{H}_{2}$ - A considerable number of students prefer a cross-sectional approach based on judgments to study ethical competences.

3. $\mathrm{H}_{3}$ - In the context of teaching technical perspectives instead of ethical ones, students compromise their personal (ethical) gain by behaving unethically.

4. $\mathrm{H}_{4}$ - At present, ethics is regarded as important for students' future employment in companies.

5. $\mathrm{H}_{5}$ - From students' perspectives, ethical behaviour has important consequences for employees, companies and society.

Thus, a first general meeting was convened to shape the work practices and the phases of the project. Six meetings were held over a period of two months, and the project was divided into nine stages: 1) Training activity on the concept of "ethical commitment" by an ethics teacher; 2) Selection of the court judgments to be studied; 3) Drafting of a questionnaire based on the project objectives; 4) Study of the court judgment by the teachers, determining the number of unethical behaviours and their typologies; 5) Conducting a pre-test among the students; 6) Organising the completion of the study by teachers; 7) Data tabulation; 8) Presenting the study to those responsible for the Innovation Project; and 9) Holding a meeting to assess the results with teachers.

The Innovation Group started with a total of 25 judgments extracted from the database of the General Judiciary in Spain during the years 2013 and 2014. In choosing the final judgments, and the group focused on ones related to economic, financial and management matters. Obviously, the judgment with the highest number of illegal acts (and implicit unethical behaviour) was accepted, but the selection also included judgments that were in line with other determining factors, such as: 
1. Extension of the judgment. The "issues of fact" should not exceed 10-15 pages to ensure the students could read it in class or at home.

2. Non-discriminatory. The content of the judgment should not include statements that could be regarded as discriminatory behaviour based on race, social matters, religion, etc.

The selection criteria were based on the eight illegal acts appearing in the judgments and classified in the categories below, ordered from $\mathrm{A}$ to $\mathrm{H}$.

The three judgments finally chosen from the initial selection were those that included the highest number of illegal behaviours, so as to obtain a greater representation in a single document. These were: 16/2013 of the High Court of Andalusia (TSAR), 307/2014 of the Provincial Court of Zaragoza and 35/2014 of the Provincial Court of Guadalajara.

\begin{tabular}{|c|c|l|}
\hline \multirow{4}{*}{ Table 1: List of illegal acts } & Ase of public information for private purposes \\
\cline { 2 - 3 } & B & Labour exploitation \\
\hline C & Manipulation of balances \\
\hline D & Biased economic information \\
\hline E & Strategies for tax evasion \\
\hline F & Flight of capital \\
\hline G & Tax falsehoods and inaccurate documentation \\
\hline H & Unfair competition \\
\hline
\end{tabular}

To familiarise the members of the team with these judgments, a law professor and specialist in this area of knowledge prepared a brief summary of the three judgments, which were later given to the university students participating in the study, and which read as follows:

1. Judgment 16/2013 of the High Court of Andalusia, Social Chamber. An appellate judgment concerning a disciplinary dismissal. The dismissal letter contained therein was very interesting for our purposes and it also served to explore other circumstances where the employer used public information for private benefit. It was about the dismissal of a female worker by the company director, who was in fact the employee's husband. The female employee had managed to slip through several controls and audits.

2. Judgment 307/2014 of the Provincial Court of Zaragoza. This is a judgment based on the acts of a mayor who carried out some urban development projects, setting up a public company that traded urban soil for housing and other infrastructures in exchange for a symbolic price. Other companies were involved in the plot, which was further complicated by fraudulent grants and complaints from the opposition councillors.

3. Judgment 35/2014 of the Provincial Court of Guadalajara. Many censurable acts also converge in this case. Chinese entrepreneurs executed slave contracts with other compatriots who were brought to Spain fraudulently. National entrepreneurs collaborated in this business. The judgment contained a number of cases of Social Security system fraud, which violated some of the most basic labour laws, in addition to others that would simply be classified as human errors.

Despite the third judgment being the one encompassing the most offences, we noted from the summary that it entailed considerable discrimination towards the 
Chinese community in Spain, which was not in line with the criteria used to choose the judgments, as outlined above (i.e. extension and non-discrimination). This explains why we chose the judgment of the Supreme Court of Andalusia for the purposes of our study.

At a subsequent meeting, the working group discussed the content of the questionnaire presented to the students through the Google Doc tool to make any necessary improvements. Several questions were clarified to ensure optimal student understanding.

In the context of anonymity, a set of personal questions constituted the first block of the questionnaire. This information included respondents' age, gender, degree, course, campus, subject, teacher and average marks of the previous year.

The second block of questions, related to "Teaching Ethics through Court Judgments" in the first part of Figure 3, was designed to ascertain the number of unethical behaviours students were able to detect in the judgment, prioritising the three they considered most important. Then, in order to build ethical decisionmaking skills, we divided the second block into two main sub-sections called "University" and "Company", according to the ethical aspects (see Figure 3).

Figure 3: Process for teaching ethics through judgments and sentences

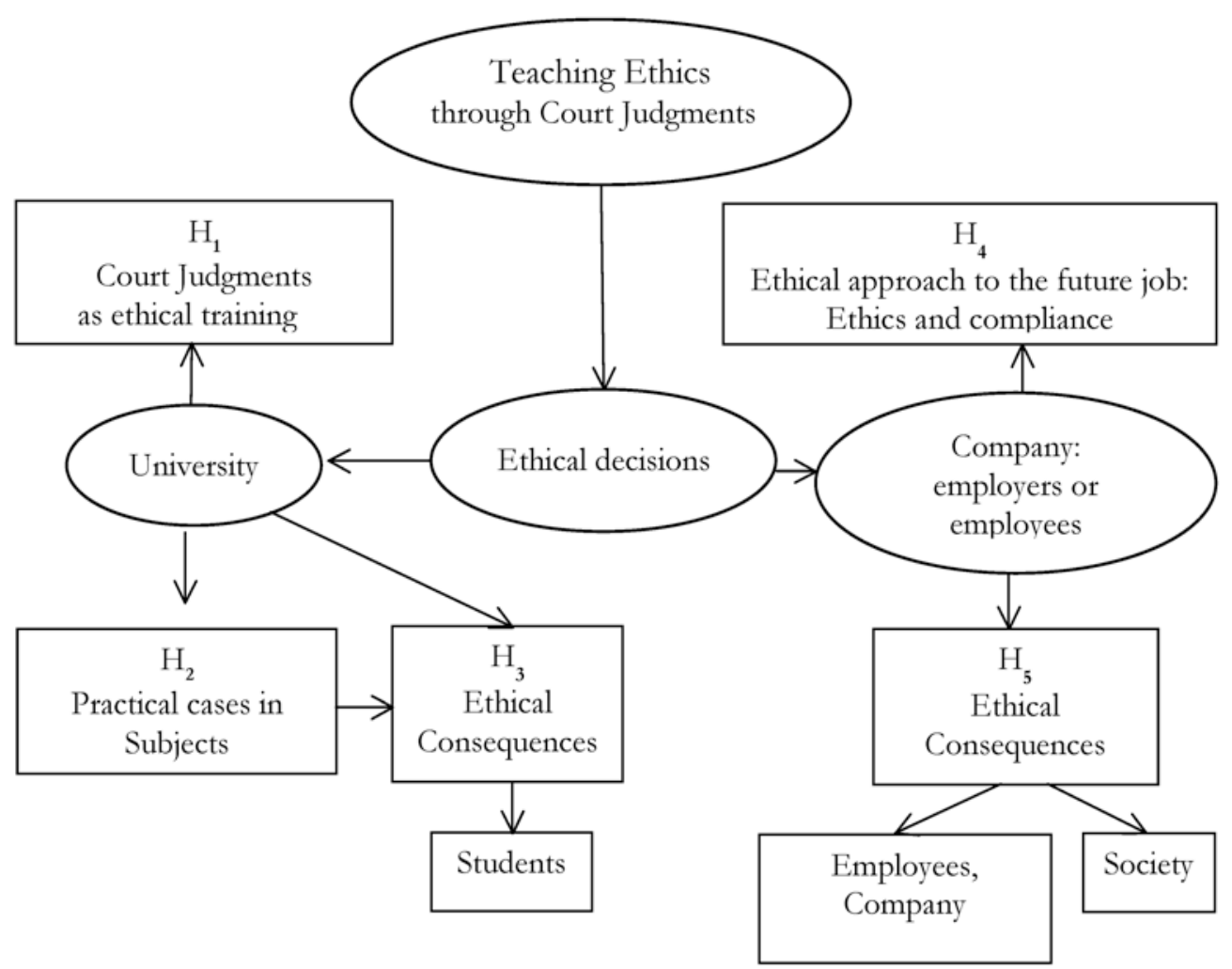

The University section focuses on options for incorporating practical crosssectional studies based on court judgments into each subject. Student feedback was collected on specific options for how to tackle the effects of unethical behaviour at University, such as plagiarism and cheating on exams. This block also compares the methodology based on judgments with other methodologies, such as: "Classes on ethics in the form of seminars or additional courses", "Showing movies with ethical content", "Reading business news about ethics". This block of issues addresses hypotheses $\mathrm{H}_{1}, \mathrm{H}_{2}$ and $\mathrm{H}_{3}$. 
In the Company section, students were asked about aspects related to their future employment within a company (as employers or employees) under the framework of the recently amended L.O. 1/2015, of 1 July. That law compels all companies to implement "special control and surveillance measures" based on ethical codes. The answers show how much importance students assign to ethical conduct in companies, and what ethical consequences the unethical behaviour has for them and also for society in general. Hypotheses $\mathrm{H}_{4}$ and $\mathrm{H}_{5}$ are analysed in this section.

Once the information was properly structured, a pre-test was conducted in a class of 20 students to validate the questionnaire.

In order to complete the test, we prepared a PowerPoint presentation that explained the objectives of the project. The objectives were based on two aspects: being able to detect illegal and unethical behaviour and proposing improvements through ethical decisions.

The students used a computer to complete the questionnaire and had two hours to do so. The results were generated automatically and downloaded into an Excel spreadsheet.

\section{Results}

The survey was conducted between 20 February and 20 May 2015. A total of 467 students participated, but 11 questionnaires were discarded for not complying with the questionnaire requirements. The final sample thus consisted of 456 students.

The study was conducted with graduate level students in the areas of Finance and Accounting, Business, Economy, and Law and Sociology at the University of Extremadura.

As far as the distribution by academic year, more $1^{\text {st }}$-year students (43\%) participated than students in their $3^{\text {rd }}$ year $(26 \%)$. The participation rate was under $20 \%$ for students in other years: $2^{\text {nd }}$ year $(18 \%), 4^{\text {th }}$ year $(12 \%)$ and other years $(1 \%)$. Over 50\% of students (233) who participated in the study were between 20 and 22 years old, and $24 \%$ were between 17 and 19 years old. Students aged between 23 and 25 , and over 26 represented $26 \%$ of the total sample. In relation to gender, the percentage of participating women (60\%), corresponding to 273 students, was higher than men (40\%), or 183 students.

The 456 students participated in the study through different subjects, such as: Financial Accounting and Companies I and II (19\% and 29.28\%, respectively), Strategic Management (16\%), Sociology (15\%), Business Administration II (10\%), Financial Planning and Business Valuation (13\%) and less than 10\% from other subjects: Sociology of Leisure and Tourism (8\%), Business Administration (7\%), Business Economics (5\%). Finally, less than 5\% of participants came from the courses Sociology of Gender Relations and Families, Introduction to Statistics, Introduction to Business Research and Tourism III, and Marketing and Administrative Law.

\section{Hypotheses}

$\mathrm{H}_{1}$-Students highly value studying ethics through court judgments based on "legal/illegal acts and ethical/unethical behaviour"

Ethical competences might be developed first through a vertical approach, such as studying philosophical principles in class (Felton \& Sims 2005; McDonald 2004), 
seminars on ethics (Oddo 1997, 293) or including courses on ethics as an additional subject (Moore 2004, Ritter 2006 Thornberg 2008); Secondly, a cross-sectional perspective could be incorporated by dealing with ethical dilemmas (Zych 1999), watching movies from corporate standpoints (Higgins \& Striegel 2003) or through the subject matter of this article, learning through legal judgments.

In this regard, students were asked Question 1: Which methodology would be the best to help you improve your ethical attitudes in the field of business? Select the response that interests you most. The most selected response was "Cross-sectional cases, learning through judgments" (40\%), about double the number compared to the others, namely "Cross-sectional learning through business dilemmas" (21\%), "Classes on ethics either in the form of seminars or additional courses" (20\%), "Showing movies with ethical content" (14\%), and finally, "Reading business news about ethics" (4\%) (See Table 2). Thus, a large percentage of the students favour learning ethics through cross-sectional cases rather than a vertical approach. Within the cross-sectional approach, they strongly prefer to arrive at ethical decisions through judgments rather than solving ethical business dilemmas. The reason for this may come from the recent compliance actions in Spain, in which the prevention of illegal behaviours in companies affects not only firms but also employees. Consequently, students who will join company ranks after finishing their degrees want to learn how they will be able to cope with the law's negative consequences through behaving more responsibly.

Table 2: Methodologies to enhance ethical attitudes

\begin{tabular}{|l|c|c|}
\hline Methodologies & Valid \% & Frequency \\
\hline $\begin{array}{l}\text { Classes on ethics either in seminars or additional } \\
\text { courses }\end{array}$ & $20 \%$ & $\mathbf{9 2}$ \\
\hline Cross-sectional cases, learning through judgments & $40 \%$ & $\mathbf{1 8 4}$ \\
\hline Cross-sectional learning through business dilemmas & $21 \%$ & $\mathbf{9 5}$ \\
\hline Reading business news about ethics & $4 \%$ & $\mathbf{2 0}$ \\
\hline Displaying movies with ethical content & $14 \%$ & $\mathbf{6 5}$ \\
\hline Total & $100 \%$ & $\mathbf{4 5 6}$ \\
\hline
\end{tabular}

However, based on this ethical training, students become aware of differences in business practices, whether illegal, unethical or both. Ethical training is important for two reasons: first, to familiarise students with the illegal acts appearing in the judgment, which can result in sanctions that cause personal and organisational damage; and second, to help students see wrong behaviour in order to make ethical decisions, which is the ultimate aim of this research.

Related to the first goal, we asked students Question 2: The General Judiciary in Spain classified different groups of illegal acts between 2013 and 2014 (unfair competition, labour exploitation, the use of public information for private purposes, tax falsehoods and inaccurate documentation, strategies for tax evasion, flight of capital, biased economic information and manipulation of balances). Can you identify how many of these appear in the judgment?

From the results, it appears that students generally saw three illegal acts in the judgment: "the use of public information for private purposes", "tax falsehoods and inaccurate documentation" and "biased economic information". 95\% and 92\% of students spotted the first and the second acts, respectively, while the third act was selected by $84 \%$ of students. 
In order to take the concept of "ethical decisions" further, we adopted a broader framework, moving from illegal acts to unethical behaviour. So we asked students Question 3: If you identified any unethical behaviour, please indicate the three you found most important. An example was added to ensure that they understood the question properly: Answer by putting them in order of importance, summarising their contents in a brief sentence, for example: 1. Employee abuse. 2. Misappropriation of company funds, etc.

According to the questionnaire, and considering the crimes and/or unethical behaviour cited most by students, we observed that they were capable of differentiating between "illegal acts" and "unethical behaviour", although they were not able to pinpoint the exact regulation behind them due to a lack of legal knowledge.

Table 3 represents the main illegal acts and unethical behaviours pointed out by students from the sample (439 responses). We had the support of a law professor to confirm the illegal acts and clarify whether these acts can be classified in the $4^{\text {th }}$ case or not.

Table 3: Main illegal acts and unethical behaviours noted in the court judgment

\begin{tabular}{|c|c|c|}
\hline Behaviours & $\begin{array}{l}\text { Ethical } \\
\text { consequences }\end{array}$ & Unethical consequences \\
\hline $\begin{array}{l}\text { Acts } \\
\text { accepted by } \\
\text { the law }\end{array}$ & $\begin{array}{l}\text { High } \\
\text { percentage: } \\
1^{\text {st }} \text { case }\end{array}$ & $\begin{array}{l}\text { Low percentage: } 2^{\text {nd }} \text { case } \\
\text { 1) "Hiring his wife, daughter or son" }(41 \%) \text {. } \\
\text { 2) "Not making up the hours that were not worked } \\
\text { "( } 31 \%) \text {. } \\
\text { 3) "Concealing the fraud in email correspondence } \\
\text { (29\%) } \\
\text { 4) "Allocating functions that do not belong to them" } \\
\text { (37\%) }\end{array}$ \\
\hline $\begin{array}{l}\text { Acts } \\
\text { prohibited } \\
\text { by the law }\end{array}$ & $\begin{array}{l}\text { Very low } \\
\text { percentage: } \\
3^{\text {rd }} \text { case }\end{array}$ & $\begin{array}{l}\text { High percentage: } 4^{\text {th }} \text { case } \\
\text { 1) "The use of public information for private } \\
\text { purposes" (95\%) } \\
\text { 2) "Tax falsehoods and inaccurate documentation" } \\
(92 \%) \\
\text { 3) "Biased economic information" (84\%) } \\
\text { 4) "Collecting more hours than those worked" (81\%) } \\
\text { and "collecting non-existent bonuses" }(76 \%) \text {. } \\
\text { 5) "Working fewer hours than those contracted" } \\
(43 \%) \text { : } \\
\text { 6) "Forgery" }(49 \%)\end{array}$ \\
\hline
\end{tabular}

With the illegal acts and unethical behaviours in mind, we asked students to analyse whether it was possible to make correct decisions to ascertain the judge's opinion beforehand. After the students had read the case, we asked them Question 4: Do you think one can take the right decisions from the point of view of business and professional ethics in the case we are analysing? The importance of this question lies in student's ability to identify possible improvements of the judgment in question from an ethical point of view. Through "moral imagination", we asked them to try and see the situation through the eyes of others and solve the illegal and unethical behaviour detected in the judgment (Biss 2014). 
Students could respond in three ways. If students responded negatively, they would rule out any option for improving the management of the company from an ethical point of view. Conversely, if they answered positively, it would demonstrate that students were not only aware of the mistakes the company made, but also that they already have the knowledge to redirect unethical behaviours towards ethical ones. In the third case, students were aware that the behaviour was misinterpreted and badly applied but did not know the solution.

Table 4: Ability to make

\begin{tabular}{|l|c|c|}
\hline Consequences & Valid percentage & Frequency \\
\hline Yes & $69 \%$ & 316 \\
\hline No & $3 \%$ & 12 \\
\hline Don't know & $28 \%$ & 128 \\
\hline Total & $100 \%$ & 456 \\
\hline
\end{tabular}

Thus, the teacher's task should focus on providing decision-making tools for students who have answered positively, which, as indicated in Table 4, represented more than two-thirds (69\%) of the respondents. The aim would be to prioritise the potential measures to be taken. Almost $30 \%$ do not have sufficient arguments to make ethical decisions, but approximately one-third do. This shows that there is still a long way to go to demonstrate the importance of ethics in decision-making and the methods to correct any wrong decisions.

As mentioned above, the aim of this study is to raise university students' awareness of the legal boundaries of their behaviour and the unethical behaviour linked thereto. It also addresses a second phase focused more on reorienting such illegal behaviour. Thus, in this study, students were asked to provide answers in relation to a real and objective situation that could occur in the future, organised by the degree of importance they assigned according to their priorities. In short, from a context of ethical reflection on actions and behaviours, students suggested different ways to reorient the conduct sanctioned by law, thus addressing the goal of this research.

This process also allowed us to classify how students prioritised decisions when discussing matters related to ethical aspects that are of greatest concern to them. Reflecting on unethical and/or criminal behaviours necessarily involves students taking ethical decisions. To this end, we asked Question 4.1: Describe three ethical decisions that could have prevented what happened. Write them in order of importance. Of the 316 students who answered correctly, many of them formulated different solutions that could have been adopted to prevent the penalty imposed in the judgment.

From among the ethical decisions made by students (Figure 4), those focusing on behaviours related to "preventing the abuse of power" by using a job title or position for personal gain are worthy of mention. Secondly, students (135) highlighted the importance of "employees complying with the company rules" and thirdly, "returning overcharged money" (115 students).

For Ethical Decision 2, 168 students rated as highest the need to improve (through courses and/or training) the "honesty" that managers should demonstrate towards employees when performing their job. In second place, 135 students thought that the Human Resources Department should address the problems of improper hiring and thus "eliminate favouritism in the company"; and thirdly, 105 students said that "receiving a course in business ethics" would be helpful to 
improve their ethical behaviour as employees. As can be seen, students feel it is important to address ethical procedures in order to develop the ethical view of managers and employees, as "compliance measures" suggest.

In Ethical Decision 3, the top priority is to make the recruitment system more professional by "adjusting the recruitment process to professional criteria" (160 students); in second place, "returning overcharged money" (148 students) and finally, "employees complying with the legal rules" (144 students). Ethical decisions to be taken in the company refer to a lesser extent to "promoting transparency in the company", "separating professional from personal life" and "incentivising employees to improve productivity."

Thus, to adopt the measures they would normally take in order to act properly in the company, students proposed on the one hand to eliminate unethical behaviour such as "the lack of managerial supervision over the team" and "failure to report information to the service manager but to the manager instead"; and on the other hand, they highlighted "ethical acts" such as: "sending the accountancy books to the general director and area managers", "tracking the hours worked and extra hours on the CLAU programme" and "the General Manager's discovery of a dysfunction in the price/real time spent on the service". All of these issues could have been resolved if companies and employees had developed their "compliance surveillance measures".

Figure 4: Ethical decisions taken by students

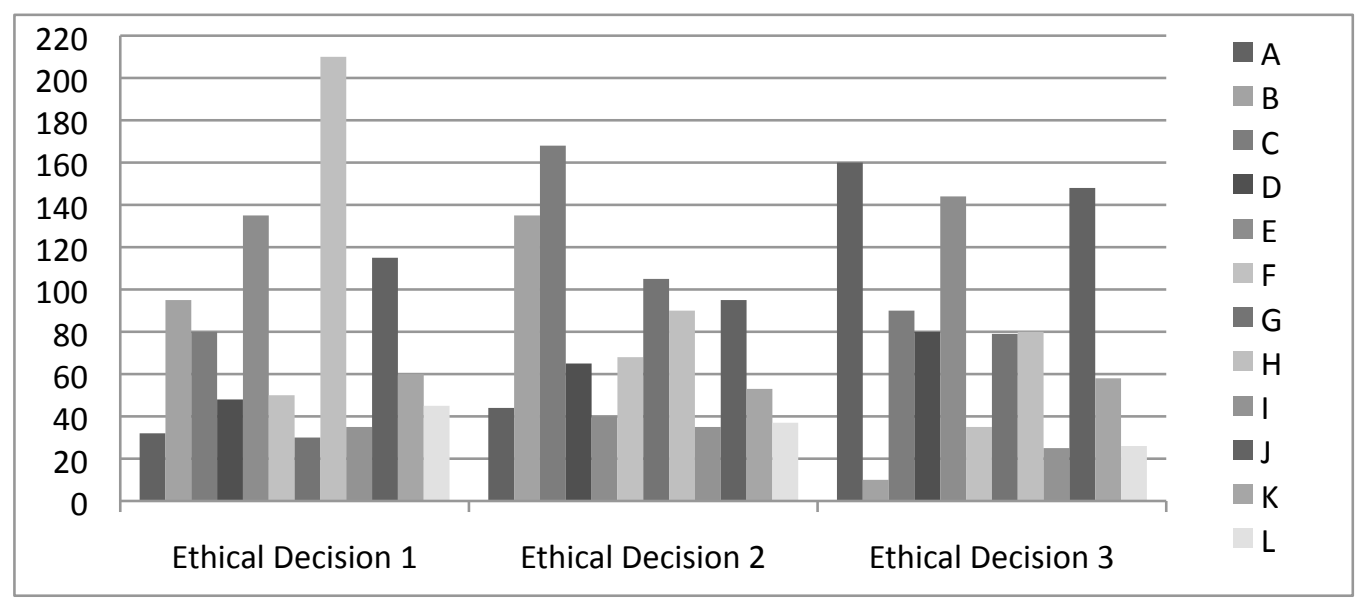

A. Adjusting the recruitment process to professional criteria

B. Eliminating favouritism in the company

C. Promoting the honesty of managers towards their employees

D. Imposing adequate punishments or dismissal

E. Employees complying with the rules

F. Promoting transparency in the company
G. Receiving a course on business ethics

H. Preventing the abuse of power

I. Worker collaboration to solve problems

J. Returning overcharged money

K. Separating business from personal life

L. Incentivising employees to produce an effect on productivity 
$\mathrm{H}_{2}-\mathrm{A}$ considerable number of students prefer a cross-sectional approach based on judgments to study ethical competences

Upon finding that students considered "cross-sectional learning through judgments" to be a relevant tool to study ethics at the university in the Financial, Business and Accounting areas, the Innovation Group was interested in ascertaining whether students would be willing to include ethics in the curricula of each subject. To this end, students were asked Question 5. In order to promote this competency and deepen knowledge, do you think practical exercises and case studies should be included in the curricula of each subject? The responses obtained and represented in Table 5 show that $91 \%$ of the students favour this type of participatory methodology. This result supports Hypothesis 2 and is the path being taken by the Educational Innovation Group.

Before including these cross-sectional cases, it is relevant to know whether teachers currently ever make any ethics references in their classes. To date, no teachers in the above programmes have explicitly included content related to "ethical commitment" in the subjects per the guidelines issued by the competent authorities on how to prepare the syllabi in Finance and Accounting, Business Management and Tourism education. This explains Question 6: Did the teacher dedicate a section of the subject to ethics? If so, how much? As stated in Table 6, 89\% of students said that scattered references to ethics were made in class (specifically, only one class on average), and thought it would be helpful if the teachers were able to include more structured ethical cases. This is further proof that business and financial education continues to be based on pragmatic, superficial and utilitarian content instead of ethical content (Cragg 1997, McDonald 2004, Sims \& Felton 2006, Sánchez 1997).

Table 5: Including cross-sectional learning through judgments in the curricula of each subject

\begin{tabular}{|l|c|c|}
\hline Methodologies & Valid \% & Frequency \\
\hline Yes & $91 \%$ & $\mathbf{4 1 7}$ \\
\hline No & $4 \%$ & $\mathbf{2 0}$ \\
\hline Don't know & $4 \%$ & $\mathbf{1 9}$ \\
\hline Total & $100 \%$ & $\mathbf{4 5 6}$ \\
\hline
\end{tabular}

Table 6: References to ethics in class

\begin{tabular}{|c|c|c|}
\hline Value labels & Valid percentage & Frequency \\
\hline Yes & $89 \%$ & 405 \\
\hline No & $11 \%$ & 51 \\
\hline Total & $100 \%$ & 456 \\
\hline
\end{tabular}

$\mathrm{H}_{3}-$ In the context of teaching technical perspectives instead of ethical ones, students compromise their personal (ethical) gain by behaving unethically

Pragmatic, superficial and utilitarian content taught at university focus exclusively on competitiveness and outcomes (Cragg 1997, McDonald 2004, Sims \& Felton 2006, Sánchez 1997) and maximising profit (McDonald \& Donleavy 1995: 841, Gavin \& Klinefelter 1988: 24) but need to be supplemented with ethical knowledge. 
Table 7a: Plagiarism at the University

\begin{tabular}{|l|c|c|}
\hline Consequences & Valid \% & Frequency \\
\hline Yes & $35 \%$ & 158 \\
\hline No & $57 \%$ & 260 \\
\hline Don't know & $8 \%$ & 38 \\
\hline Total & $100 \%$ & 456 \\
\hline
\end{tabular}

Some authors have explained the consequences of this type of teaching in Financial, Business and Accounting areas for students, saying it can compromise students' ethical principles for personal gain and be used as a vehicle for personal success (Ureña 1999), (Teixeira \& Rocha 2010). Obvious dysfunctions are noted, such as: plagiarism, which is perceived as a growing problem requiring increased time and resources to combat (Smith et al., 2007) (Gullifer \& Tyson 2010) and cheating on exams (Amen et al., 1996), (Rakovski et al., 2007). Given these circumstances, we asked students Question 7: Have you ever committed plagiarism in your classwork, thereby cheating yourself and your teachers? Have you ever copied in an exam, thereby cheating yourself and your teachers? As we can see in Tables $7 \mathrm{a}$ and $7 \mathrm{~b}, 35 \%$ of students openly confess that they have written essays unethically, and in some cases, even illegally. Also, $26 \%$ of students often copy in exams. These percentages correspond to findings upon which Hypothesis 3 is based, and are an increasing concern for teachers at the University of Extremadura for two reasons: first, if students fail to comply with the rules at university, they will most likely do the same in their future work; second, these unethical behaviours are another consequence of teaching from only a pragmatic and utilitarian approach, where ethics are not taught or considered.

\section{$\mathrm{H}_{4}$ - At present, ethics is regarded as important for students' future employment}

After being asked about the options for incorporating ethical decisions that help reorient unethical behaviour, it is important to ascertain how relevant students believe ethics is for their future professional career. The amended version of the Spanish Criminal Code (L.O. 5/2010) is being applied in order to introduce "special control and surveillance measures" to ensure compliance with the law. Now, more than ever, it is extremely important "to promote a culture of respect towards the right decisions" (Supreme Court, 20.02.2016) by implementing "codes of practice". Although these professional codes of ethics are not yet practiced openly in companies (Pater Van Gils, 2003), they can be useful to companies if the models for cooperation are integrated into the organisation and its operations management (Wieland, 2015). This is a point of orientation for professional action and legal evaluation (Hubig, 2001).

Table 7b: Copying in University exams

\begin{tabular}{|l|c|c|}
\hline Consequences & Valid \% & Frequency \\
\hline Yes & $26 \%$ & 118 \\
\hline No & $70 \%$ & 320 \\
\hline Don't know & $4 \%$ & 18 \\
\hline Total & $100 \%$ & 456 \\
\hline
\end{tabular}


Students were then asked Question 8: Developing a profession ethically means always trying to ensure that our work conforms to a set of codes, such as "not committing fraud", "transparency" and "honesty". How important is this for you in your future job?" As shown in Table 8, three-quarters of the students (74.99\%) considered these codes for ethical conduct to be very important in their future jobs, and $22 \%$ believe it to be fairly important. These results are in alignment with Hypothesis 4. It is surprising to see that no students responded "not important" and only one out of the 456 students answered "somewhat important". The results gave the group a better idea of the scope of what is really needed to address this type of knowledge in teaching.

Table 8: Importance of ethics in students' future jobs

\begin{tabular}{|l|l|c|}
\hline Importance & Valid Percentage & Frequency \\
\hline Not important & $0 \%$ & 0 \\
\hline A bit important & $0,01 \%$ & 1 \\
\hline Somewhat important & $3 \%$ & 12 \\
\hline Quite important & $22 \%$ & 101 \\
\hline Very important & $74,99 \%$ & 342 \\
\hline Total & $100 \%$ & 456 \\
\hline
\end{tabular}

$\mathrm{H}_{5}-$ From students' perspectives, ethical behaviour has important consequences for employees, companies and society

In light of this consideration, we asked Question 9: If you had to categorise the consequences that such behaviour has for the company, what value would you give them? As shown in Table 9, 57\% of students answered "Quite a number of consequences, as the company's productivity and its corporate image would be affected" and 38\% answered "Many consequences: unethical behaviour detected in this case seriously damages the company". This shows that $95 \%$ of students are highly aware of the close relationship between ethical behaviour and company activities. In addition, student responses show they were relating ethics not only to internal attitudinal aspects of companies, but also to other external factors which are highly valued by companies, such as "productivity" and "corporate image". Among the main consequences of unethical behaviour for the company are: "increased costs, losses in service", "bad image for the customer", "loss of confidence of the managers with respect to employees", and "favouritism in the recruitment process".

Table 9: Consequences of unethical behaviour for companies

\begin{tabular}{|l|l|l|}
\hline Consequences & Valid \% & Frequency \\
\hline None. They are widespread practices in economic life. & $1 \%$ & 5 \\
\hline $\begin{array}{l}\text { Some. This type of unethical behaviour could have some } \\
\text { consequences for business life. }\end{array}$ & $4 \%$ & 18 \\
\hline $\begin{array}{l}\text { Quite a number of them, as they affect the productivity } \\
\text { and corporate image of company. }\end{array}$ & $57 \%$ & 261 \\
\hline $\begin{array}{l}\text { Many: the unethical behaviour detected in this case is } \\
\text { seriously detrimental to the company. }\end{array}$ & $38 \%$ & 172 \\
\hline Total & $100 \%$ & 456 \\
\hline
\end{tabular}


The connotations of such behaviour not only transcend the legal entity, but are also reflected in the individual, i.e. among colleagues united by a professional relationship. This explains Question 10: Imagine a relationship between co-workers that involves unethical behaviour. Classify the consequences it has for the other coworkers. In this case, "abusing their trust" and "developing unethical behaviour" can be quite harmful to others. In fact, at a rate somewhat lower than the consequences for the company but also noteworthy, $54.70 \%$ of students believed that acting unethically would have "quite a number of consequences," arguing that "bad business practices may affect personal, professional and family life". Similarly, and to an even greater degree of gravity, nearly $30 \%$ believed that "bad business and professional practices" would certainly have many consequences (see Table 10).

If we limit ourselves to the societal level, we can see that unethical behaviour can sometimes have a social impact beyond that of a strictly professional or business relationship. In this case, we can standardise a series of behaviours that affect not only the relationships between professionals and companies, but can also become part of the very culture of societies. Attitudes such as: unpaid taxes, capital flight, respect towards employees' rights and correct treatment within the company, may become favourable or contrary to the society that employees and businesses share.

We then formulated Question 11: If you had to classify the consequences such behaviour has for society, what value would you give them? In this regard, and as shown in Table 11, students detected how serious "unethical behaviour" is for society and how it transcends to other spheres for their adverse effect on society. More often than not, these behaviours take the form of crimes - regardless of whether or not they are eventually proven. Just over one-third (39\%) said that unethical behaviour has "quite a number of consequences, as bad business practices can affect the social life as a whole". Almost as many students (35\%) believed that it has "many consequences: unethical behaviour detected in the company undoubtedly transcends to society and a corrupt environment becomes widespread". Overall, most students are pretty aware of the consequences of unethical conduct for the company, co-employees and society, as predicted in Hypothesis 5.

Table 10: Consequences of unethical behaviour for colleagues

\begin{tabular}{|l|c|c|}
\hline Consequences & Valid \% & Frequency \\
\hline $\begin{array}{l}\text { None. They are widespread practices in economic life } \\
\text { and society is generally sympathetic towards these } \\
\text { professionals and entrepreneurs. }\end{array}$ & $3,31 \%$ & 12 \\
\hline $\begin{array}{l}\text { Some. People may be somewhat affected, but their life } \\
\text { remains the same and they are still recognised and } \\
\text { appreciated socially and professionally. }\end{array}$ & $12,15 \%$ & 41 \\
\hline $\begin{array}{l}\text { Quite a number of them, as bad business practices may } \\
\text { affect personal, professional and family life. }\end{array}$ & $54,70 \%$ & 255 \\
\hline $\begin{array}{l}\text { Many: bad professionals and business practices can } \\
\text { certainly affect personal, professional and family life. }\end{array}$ & $29,83 \%$ & 148 \\
\hline Total & $100 \%$ & 456 \\
\hline
\end{tabular}


Table 11: Consequences of unethical behaviour for society

\begin{tabular}{|l|c|c|}
\hline Consequences & Valid \% & Frequency \\
\hline $\begin{array}{l}\text { None. They are widespread practices in economic life } \\
\text { and society is generally sympathetic towards it. }\end{array}$ & $4 \%$ & 19 \\
\hline $\begin{array}{l}\text { Some. These types of unethical behaviour may affect } \\
\text { social life to some extent. }\end{array}$ & $21 \%$ & 97 \\
\hline $\begin{array}{l}\text { Quite a number of them, as bad business practices can } \\
\text { affect social life as a whole. }\end{array}$ & $39 \%$ & 179 \\
\hline $\begin{array}{l}\text { Many. The unethical behaviour detected in the } \\
\text { company, transcends to society and a corrupt } \\
\text { environment becomes widespread. }\end{array}$ & $35 \%$ & 161 \\
\hline Total & $100 \%$ & 456 \\
\hline
\end{tabular}

\section{Discussion}

The unexpected relevance of Spanish corporate scandals, reflected in more than 4000 business judgments issued in the last two years due to a corrupt manner of managing companies, has forced the General Council of the Judiciary to take measures to stop this behaviour.

In the framework of the recently amended_L.O. 1/2015, of $1^{\text {st }}$ July, which compels all companies to implement "special surveillance measures" based on ethical codes, companies are now required to build a culture of respect towards the law through developing ethical codes. This culture of ethics must begin and be learnt at university.

Students from the Financial, Business and Accounting areas of the University of Extremadura are more than willing to build their ethical commitment through cross-sectional cases, learning through judgments. This methodology was selected to familiarise students with illegal acts and unethical behaviours revealed in the judgments. The ultimate aim of this research is for ethical decisions to be arrived at from studying these prohibited acts. Moreover, this is the preferred way for those students to develop "ethical competences" as outlined by the academic programmes of Royal Decree 1393/2007, of 29 October governing Official University Education in Spain.

Thus, through judgments, students can develop "moral reasoning" as well as "moral imagination", increasing their ability to see the situation through the eyes of others and to solve the problem by simulating being a person in charge of the company (Biss 2014).

In contrast with the difficulties in teaching ethics in the areas of Finance and Accounting, and Economics and Business (Argandoña 1999), students would normally deal with comparable ethical situations (Maclagan 2015) based on "illegal acts and unethical behaviour" in real companies. In fact, more than two-thirds (69\%) of the students who participated in the research found that ethical decisions must be taken in order to prioritise any potential surveillance measures.

Hence, the lack of teachers' in-depth knowledge of ethics (Oddo 1997, Colnerud \& Granström 2002) ceases to be a barrier to teaching ethics in this case. The objectivity of the judgment subjected to the evidence phase and then, the final 
decision of the judge sets the limits and guidelines to determine the acts that are legal or illegal according to law. From this we can determine which ethical decisions must be made to correct such illegality, under the guidance of the team of teachers participating in this Innovation Project.

In this sense, developing ethical commitments is important for students not only because most companies will have to propose such surveillance measures according to the Spanish Criminal Code, but for two further reasons: first, the lack of university training on ethical education (none of the teachers in Financial, Business, or Accounting explicitly teaches ethics in their courses, and on average, they only mention ethical approaches in one class); second, the percentage of students who appear to be cheating nowadays, either by copying essays or in exams, is considerable.

Contrary to what was detected by some authors (McDonald, \& Donleavy 1995: 841, Gavin \& Klinefelter 1988: 24), overall, the Innovation Group detected an interest in and a suggestion of ethics teaching in each of the classrooms. In fact, $91 \%$ of the students who participated in the study were in favour of including this type of participatory methodology (Table 5) during their classroom sessions. These results validate this methodology in classroom teaching in subjects related to Finance and Accounting, and Economics and Business.

\section{Limitations}

The methodology used in this study presented different limitations, which must be conveyed. Initially, we had 25 judgments, but we had to select only the most suitable for students, bearing in mind the need to be careful with the "extension" and the possible "discrimination" aspects. From this sample, we rejected approximately half of the judgments because of their extension. Some of the judgments chosen also had to be rejected in the end due to discrimination issues.

We had the added difficulty of working with students who may not have been familiar with the complexity of legalese. We therefore had to take the necessary measures to facilitate their understanding of the judgments. In this case, we briefly summarised the court judgments and the plot of the case and then presented them to students. At the beginning of the classes, we took five minutes to ensure students could easily understand the court judgments.

\section{Acknowledgements}

We are deeply grateful, first of all, to the group of teachers who have collaborated in this study and in particularly to those who formed the research team. We would also like to thank the students who were willing to spend their time participating in this study, which has been useful in increasing their level of ethical knowledge.

Lastly, we would like to say that this article and all the research behind it have only been possible thanks to the collaboration of the European Regional Development Fund (FEDER) and the regional Extremadura government, called "Junta de Extremadura". 


\section{References}

Adam, A., \& Rachman-Moore, D., (2004). The Methods Used to Implement an Ethical Code of Conduct and Employee Attitudes, Journal of Business Ethics, Vol. 54, pp. 225-244. http://dx.doi.org/ 10.1007/s10551-004-1774-4

Alvarez Pastor, D., \& Eguidazu Palacios F., (2006). Manual de prevención del blanqueo de capitales, Marcial Pons, Ediciones Jurídicas y Sociales, S. A. Madrid.

Ameen, E. C., Guffey, D. M., \& McMillan, J. J. (1996). Gender differences in determining the ethical sensitivity of future accounting professionals. Journal of Business ethics, 15(5), 591-597. http://dx.doi.org/10.1007/BF00381934

Argandoña, A. (1999). La enseñanza de la ética por el método del caso. En Flecha, J. R. (editor): Europa: ¿mercado o comunidad? De la Escuela de Salamanca a la Europa del Futuro ( $p$ p 4). Salamanca: Publicaciones Universidad Pontificia.

Bacigalupo, E, (2007). Falsedad documental, estafa y administración desleal, Marcial Pons, ediciones jurídicas y sociales, S. A. Madrid.

Bajo Fernández, M, (1998). Uso de información privilegiada, Cuadernos de derecho judicial, 10, 121-144. https://dialnet.unirioja.es/ejemplar/109315

Bampton, R., \& Cowton, C. J. (2013). Taking stock of accounting ethics scholarship: A review of the journal literature. Journal ofBusiness Ethics, 114(3). 549-563. http://dx.doi.org/10.1007/s10551-012-1341-3

Berton, L.: 1995, 'Business Students Hope to Cheat and Prosper, a New Study Shows', The Wall Street Journal (April 25), B1, from http://www.wsj.com/asia

Bishop, T. R. (1992). Integrating Business Ethics into An Undergraduate Curriculum, Journal of Business Ethics 11, 291-299. http://dx.doi.org/10.1007/ BF00872171

Biss M. (2014). Moral Imagination, Perception, and Judgment, The Southern Journal of Philosophy, 52, 1, 1-21. http://dx.doi.org/10.1111/sjp.12050

Bock, D. (2013). Compliance y deberes de vigilancia en la empresa. In Compliance y teoría del Derecho penal (107-122). Marcial Pons.

Bolívar, A. (2005). El lugar de la ética profesional en la formación universitaria. Consejo Mexicano de Investigación Educativa AC.

Boylan, M., \& Woolsey, I. (2015). Teacher education for social justice: Mapping identity spaces, Teaching and Teacher Education, 46, 62-71. http://dx.doi.org/ 10.1016/j.tate.2014.10.007

Buchan, H. F. (2005). Ethical decision making in the public accounting profession: An extension of Ajzen's theory of planned behavior. Journal of Business Ethics, 61(2). 165-181. http://dx.doi.org/10.1007/s10551-005-0277-2

Camargo Hernández, D. F. (2005). Evasión fiscal: un problema a resolver, $w w w$. eumed. net/libros/2005/dfcheva.

Campbell, E. (2003). The ethical teacher. Philadelphia: Open University Press.

Carroll, A.B., \& Buchholtz, A.K. (2008). Business and Society: Ethics and Stakeholder Management (7th ed.). Boston: Cengage Learning.

Colnerud, G., \& Granström, K. (2002). Respeckt för läraryrket: Om lärares yrkesspräk och yrkesetid. Stockholm: HLS Förlag. oai: DiVA.org:liu-33341

Cragg, W. (1997). Teaching Business Ethics: The Role of Ethics in Business and in Business Education, Journal of Business Ethics, 16, 231-245. http://dx.doi.org/10.1023/A:1017974908203 
Currie, G., Knights, D., \& Starkey, K. (2010). Introduction: a post-crisis critical reflection on business schools. British Journal of Management, 21 (Suppl. s1), S1-S5 http://dx.doi.org/10.1111/j.1467-8551.2009.00677.x

Dellaportas, S. (2006). Making a difference with a discrete course on accounting ethics. Journal of Business Ethics, 65(4), 391-404. http://dx.doi.org/10.1007/s10551-006-0020-7

DESECO - OCDE. (2002). Definition and Selection of Competencies: Theoretical and Conceptual Foundations. Summary of the final report "Key Competencies for a Successful Life and a Well-Functioning Society", from http://www.scielo.org.mx/scielo.php?script=sci_nlinks\&ref=2187350\&pid=S0 187-893X201300030000600007\&lng=es

Duizend J. \& McCann G. K. (1998). Do Collegiate Business Students Show a Propensity to Engage in Illegal Business Practices?, Journal of Business Ethics 17, 229-238. http://dx.doi.org/10.1023/A:1017945925104

Epstein, E. M. (1989). Business Ethics, Corporate Good Citizenship and the Corporate Social Policy Process: A View from the United States, Journal of Business Ethics, 8, 583-595. http://dx.doi.org/10.1007/BF00383027

Felton, E. L., \& Sims, R. R. (2005). Teaching Business Ethics: Targeted Outputs, Journal of Business Ethics, 60, 377-391. http://dx.doi.org/10.1007/s10551-0048206-3

Gardner, H. (2007). The ethical mind. Harvard Business Review, 85(3), 51-56. https://hbr.org/2007/03/the-ethical-mind

Gavin, T. A., \& Klinefelter D. S. (1988). Ethics in Business: Education and Internal Auditors Can Help, Managerial Auditing Journal, 3 (3), 24-26. http://dx.doi.org/10.1108/eb002814

Gili Pascual, A., (2007). Bases para la delimitación del ámbito típico en el delito de corrupción privada. Contribución al análisis del art. 286 bis del Código Penal según el Proyecto de reforma de 2007, Revista Electrónica de Ciencia Penal y Criminología, RECPC 09, pp 13. http://criminet.ugr.es/recpc/09/recpc0913.pdf

Godson, R., \& Jay Kenney, D. (2000). Introduction and overview to school-based education to counter crime and corruption: Evaluation of the initial pilot curriculum for Baja California (Mexico) and San Diego county (USA), International Perspectives, Trends in Organized Crime, March, 5, 3, 90-91. http://dx.doi.org/10.1007/s12117-000-1037-4

Gray, R., Bebbington, J., \& McPhail, K. (1994). Teaching ethics in accounting and the ethics of accounting teaching: educating for immorality and a possible case for social and environmental accounting education. Accounting Education, 3(1), 51-75. http://dx.doi.org/10.1080/09639289400000005

Gullifer J., \& Tyson G.A (2010), Exploring university students' perceptions of plagiarism: a focus group study, Studies in Higher Education, 35, (4), 463481.http://dx.doi.org/10.1080/03075070903096508

Hernández, R. Silvestri, K. \& Alvarez, A. (2007). Enseñanza de la ética en la formación gerencial. Revista de Ciencias Sociales, (Ve) [en línea], $13 \mathrm{Dj}$, from http://www.redalyc.org/pdf/280/28011681013.pdf

Hervada, J. (1992). Lecciones propedéuticas de Filosofía del Derecho, Pamplona: EUNSA, Ediciones Universidad de Navarra, S.A. 
Higgins, S., \& Striegel, C. (1999). Movies for leaders: Management lessons from four all-time great films. Spokane WA, New Media Ventures.

Higgins, S., \& Striegel, C. (2003). Movies for business: Big screen lessons in corporate vision, entrepreneurship, logistics, and ethics. Spokane WA: New Media Ventures.

Hubig, C. (2001). Ethical Codes, Professional: Engineering Codes, International Encyclopedia of the Social \& Behavioral Sciences, 4756-4759. http://dx.doi.org/10.1016/B0-08-043076-7/00194-7

Kuhlen, L. (2013). Cuestiones fundamentales de Compliance y Derecho penal. In Compliance y teoría del Derecho penal, 51-76. Marcial Pons.

L.O. 1/2015 (Constitutional Law), of 30 March, amending the L.O. 10/1995 (Constitutional Law) of Maclagan P., (2015). 23 November, of the Spanish Criminal Law, from https://www.boe.es/diario_boe/txt.php?id=BOE-A-20153439

Maclagan P., (2015). Moral dilemmas, moral reasons and moral learning: interpreting a real case in terms of particularistic theory, Business Ethics: $A$ European Review, 24, (3), 221-236. http://dx.doi.org/10.1111/beer.12071

Mahony, P. (2009). Should ought be taught? Teaching and Teacher Education, 25, 983-989. http://dx.doi.org/10.1016/j.tate.2009.04.006

Marinucci, G., \& Dolcini, E. (2002). Derecho penal" mínimo" y nuevas formas de criminalidad. Revista de derecho penal y criminología, (9), 147-168, from http://e-spacio.uned.es/fez/eserv/bibliuned:revistaDerechoPenalyCrimino logia-2002-9-5060/Documento.pdf

Marqués, P., \& Azevedo-Pereira, J. (2009). Ethical ideology and ethical judgments in the Portuguese accounting profession. Journal of Business Ethics, 86(2), 227242. http://dx.doi.org/10.1007/s10551-008-9845-6

McDonald, G. M. (2004). A Case Example: Integrating Ethics into the Academic Business Curriculum. Journal of Business Ethics. Part 1, 54, (4), 371-384. http://dx.doi.org/10.1007/s10551-004-1826-9

McDonald, G. M., \& Donleavy, G. D. (1995). Objections to the Teaching of Business Ethics. Journal of Business Ethics. Oct 95, 14(10), 839-853. http://dx.doi.org/10.1007/BF00872350

Moore, G. (2004). Business Ethics in the Curriculum: Of Strategies Deliberate and Emergent, Journal of Business Ethics, 54, 319-321. http://dx.doi.org/10.1007/ s10551-004-1821-1

Moreno-Jiménez, B., \& Rodríguez Muñoz, A. (2006). Número monográfico sobre acoso psicológico en el trabajo: una perspectiva general, Revista de Psicología del Trabajo $y$ de las Organizaciones, 22, 3, 245-249, from http://www.redalyc.org/articulo.oa?id=231317121008

OCDE. (2002). Definition and Selection of Competences (DESECO): Theoretical and conceptual foundations. Strategy Paper, from http://www.oecd.org/ document/17/0,234,en_2649_34515_2669073_1_1_1_1,00.html.

Oddo, A. R. (1997). A Framework for teaching business ethics. Journal of Business Ethics. February, 16(3), 293-297. http://dx.doi.org/10.1023/A:1017951729585

Organization for Economic Co-operation and Development, (2008), Guidelines for Multinational Enterprises, from www.oecd.org/dataoecd/56/36/1922428.pdf

Organization for Economic Co-operation and Development, (2009), Recommendation of the Council for Further Combating Bribery of Foreign 
Public Officials in International Business Transactions, (26, November, 2009), from https://www.oecd.org/daf/anti-bribery/44176910.pdf.

Pater A, \& Van Gils, A., (2003). Stimulating Ethical Decision-making in a Business Context: Effects of Ethical and Professional Codes, European Management Journal, 21, 6, 762-772. http://dx.doi.org/10.1016/j.emj.2003. 09.016

Rakovski, C. C., \& Levy, E. S. (2007). Academic dishonesty: Perceptions of business students. College Student Journal,41(2), 466. Available at URL http://connection.ebscohost.com/c/articles/25093223/academic-dishonestyperceptions-business-students

Ritter, A. (2006). Can business ethics be trained? A study of the ethical decisionmaking process in business students. Journal of Business Ethics, 68, 53-164. http://dx.doi.org/10.1007/s10551-006-9062-0

Rotsch, T. (2012). Criminal compliance. InDret, (1).

Royal Decree 1393/2007, of 29 October, establishing the planning of official university education, from https://doctorat.upc.edu/en/academicmanagement/legislation-2/rd_1393-2007

Royal Decree 55/2005 of 21 January, establishing the structure of university education and official university degree are regulated, from https://www.upf.edu/organitzacio/en/normativa/upf/normativa/doctorate/aca demic.html

Sánchez, M. A. (1997). Ética, organización y formación. REIS, 77-78, 185-198. https://dialnet.unirioja.es/servlet/articulo?codigo $=760157$

Sanger, M. N., \& Osguthorpe R., D. (2013). Modeling as moral education: Documenting, analyzing, and addressing a central belief of preservice teachers, Teaching and Teacher Education, 29, 167-176. http://dx.doi.org/10.1016/j.tate.2012.08.002

Sanger, M., \& Osguthorpe, R. (2005). Making sense of approaches to moral education. Journal of Moral Education, 34(1), 57-72. http://dx.doi.org/ 10.1080/03057240500049323

Schön, D. (1992): La formación de profesionales reflexivos. Hacia un nuevo diseño de la enseñanza y el aprendizaje en las profesiones, Barcelona: Paidós.

Shapira-Lishchinsky, O. (2011). Teachers' critical incidents: Ethical dilemmas in teaching practice, Teaching and Teacher Education, 27, Issue 3, 648-656. http://dx.doi.org/10.1016/j.tate.2010.11.003

Sia, S., (2010). Ethical Thinking and Philosophy, New Blackfriars, Volume 91, Issue 1033, 242-252. http://dx.doi.org/10.1111/j.1741-2005.2009.01301.x

Sims, R. R., \& Felton, E. L. (2006). Designing and delivering business ethics teaching and learning, Journal of Business Ethics, 63, 297-312. http://dx.doi.org/10.1007/s10551-005-3562-1

Smith, M., Ghazali, N., \& Fatimah Noor Minhad, S. (2007). Attitudes towards plagiarism among undergraduate accounting students: Malaysian evidence. Asian Review of Accounting, 15 (2), 122-146. http://dx.doi.org/10.1108/ 13217340710823350

Starkey, K., \& Tempest, S. (2009). The winter of our discontent: the design challenge for business schools. Academy of Management Learning and Education, 8 (4), 576-586. http://amle.aom.org/content/8/4/576.full.pdf

Supreme Court. Sentence 154/2016. 02/20/2016. 
Svanberg, J. (2011). How relevant is the moral intensity concept for ethics education and training? Some evidence from practicing accounting consultants. International Journal of Business Research, 11(4), 9-28. http://connection.ebscohost.com/c/articles/70065836/how-relevant-moralintensity-concept-ethics-education-training-some-evidence-from-practicingaccounting-consultants

Teixeira A., \& Rocha M.F. (2010). Cheating by economics and business undergraduate students: an exploratory international assessment, Higher Education, 59, 6, 663-701. http://dx.doi.org/10.1007/s10734-009-9274-1

The Tuning Educational Structures in Europa Project (2002), from http://tuningacademy.org/wp-content/uploads/2014/02/TuningEUI_FinalReport_EN.pdf

Thornberg, R. (2008). The lack of professional knowledge in values education, Teaching and Teacher Education, 24(7), 1791. http://dx.doi.org/10.1016/ j.tate.2008.04.004

Ureña, N. (1999). ¿Puede una escuela de contribuir a luchar contra la corrupción?, Academia. Revista Latinoamericana de Administración, 23, 104-111. http://www.redalyc.org/articulo.oa?id=71602310

Welton, R. E., Lagrone, R. M., \& Davis, J. R. (1994). Promoting the moral development of accounting graduate students: An instructional design and assessment. Accounting Education, 3(1), 35-50 http://dx.doi.org/10.1080/ 09639289400000004

Wieland, J. (2015), Ethical Codes, Professional:Business Codes, International Encyclopedia of the Social \& Behavioral Sciences (Second Edition), 21-24.

Willemse, M., Lunenberg, M., \& Korthagen, F. (2005). Values in education: a challenge for teacher educators. Teaching and Teacher Education, 21(2). http://dx.doi.org/10.1016/j.tate.2004.12.009

Willemse, M., Lunenberg, M., \& Korthagen, F. (2008). The moral aspects of teacher educators' practices. Journal of Moral Education, 37(4). http://dx.doi.org/10.1080/03057240802399269

Wines, A. W., (2008). Seven Pillars of Business Ethics: Toward a Comprehensive Framework, Journal of Business Ethics, 79, 483-499. http://dx.doi.org/ 10.1007/s10551-007-9411-7

Wulf, K. (2012), Theoretical framework, Ethics and Compliance Programs in Multinational Organizations. Springler Gabler. Research.

Zhonghai, Yu (2012). "The University's Teaching Mission Must Go beyond Exam Scores." Modern University Education, 5, 003. http://en.cnki.com.cn/ Article_en/CJFDTOTAL-YSJG201205003.htm

Zych, J. M. (1999). Integrating Ethical Issues with Managerial Decision Making in the Classroom: Product Support Programme Decisions, Journal of Business Ethics 18, 255-266. http://dx.doi.org/10.1023/A:1005871423821 